\title{
Hermeneutyka zachwytu
}

\section{Paweł Dziel}

ORCID: 0000-0002-3814-438X

John D. Caputo, określając swą hermeneutykę jako zimną, porzuca wiarę w sens. To hermeneutyka, która zatraciła swą niewinność, nie jest już aktywnością podmiotu, a raczej tym, co go w najmniej spodziewanym momencie nawiedza i zmusza do interpretacji. Ów imperatyw nie gwarantuje jednak żadnej czytelnej odpowiedzi. Nie ma żadnej tajemnicy (i to jest właściwie jedyna tajemnica) ${ }^{1}$. Podejście hermeneutyczne zaproponowane przez Adriana Glenia w książce Andrzej Stasiuk. Istnie$n i e^{2}$ dystansuje się od tak radykalnych rozwiązań, utrzymuje silne przekonanie, że proces obcowania z dziełem literackim umożliwia zbliżenie się, a może nawet dotarcie do tajemnicy.

Opolski badacz konsekwentnie eksploruje tradycję hermeneutyczną w badaniach literackich. Już od swojej książki podoktorskiej „W tej latarni...”. Późna twórczość Mirona Białoszewskiego w perspektywie hermeneutycznej (2004) koncentruje się na filozofii Martina Heideggera. Wyrazem tej postawy jest także monografia Bycie - słowo - człowiek. Inspiracje heideggerowskie w literaturze (2007), w której uwzględnione zostały zarówno rozważania teoretycznoliterackie, jak i praktyka krytyczna (autor skupił się w głównej mierze na poezji Tymoteusza Karpowicza, Mirona Białoszewskiego i Czesława Miłosza). W Istnieniu i literaturze (notatniku hermeneuty) (2010) autor nazwał uprawianą przez siebie krytykę literacką „hermeneutyką personalistyczną". Kontynuacją tej problematyki jest praca Do-prawdy? Studia i szkice o polskiej literaturze najnowszej (2012), w której dyskurs krytycznoliteracki został powiązany z fascynacją analizowaną twórczością. Rozprawa „Marzenie, które czyni poetą...”. Autentyczność i empatia $w$ dziele literackim Juliana Kornhausera to próba wskazania etycznego i metafizycznego wymiaru twórczości poety, odwołująca się w znacznej mierze do takich kategorii jak zaangażowanie i autentyczność. W pracy Czułość. Studia i eseje o literaturze najnowszej (2014) Gleń stosuje preferowany przez siebie model krytyki literackiej, cechujący się otwarciem na „obcy” język. "Wiernie, choć własnym językiem...". Rzecz o krytyce literackiej Juliana Kornhausera (2015) to natomiast studium dotyczące „krytyki empatycznej” krakowskiego pisarza. Charakteryzując dorobek badacza, nie można też pominąć faktu, że sam jest autorem kilku tomików poetyckich.

\footnotetext{
${ }^{1}$ Michał Januszkiewicz, W-koło hermeneutyki literackiej (Warszawa: PWN, 2007), 133-134.

${ }^{2}$ Adrian Gleń, Andrzej Stasiuk. Istnienie (Łódź: Wydawnictwo Uniwersytetu Łódzkiego, 2019).
} 
Książka o Andrzeju Stasiuku jest w dorobku Adriana Glenia wyjątkowa. Utrzymana w osobistym, momentami wręcz intymnym tonie stanowi odważną realizację wcześniej postulowanych przez badacza powinności literaturoznawczych. Tę formułę z pewnością dodatkowo umożliwiła koncepcja serii Wydawnictwa Uniwersytetu Łódzkiego „Projekt: egzystencja i literatura”, w której ukazała się rozprawa. Biografia, tożsamość, doświadczenie - to naczelne kategorie wykorzystywane w koncepcji cyklu do omawiania literatury. Rada naukowa serii (w skład której wchodzą Marzena Woźniak-Łabieniec, Przemysław Dakowicz i Arkadiusz Morawiec) nie tylko dzieło literackie traktuje jako „projekt egzystencjalny”, ale także - co szczególnie ważne - wykorzystuje tę samą kategorię do opisania procesu badania literatury. Wyeksponowano zatem to, co w znacznym stopniu konstytuuje współczesnych literaturoznawców: próby zapisywania siebie, rejestrowania własnego doświadczenia (kulturowego, politycznego czy historycznego, ale także cielesnego, zmysłowego lub duchowego) w kontekście odbioru tekstu literackiego ${ }^{3}$. Ponadto ważnym założeniem cyklu jest wydawanie książek o charakterze naukowym, a skierowanych do osób, które nie zajmują się zawodowo literaturą. Stąd szczególna dbałość o przystępność wywodu: unikanie hermetycznych terminów, tradycyjnie naukowego stylu czy teoretycznych polemik ${ }^{4}$. Korzystając z pewnego „rozluźnienia” metodologicznego, Gleń rezygnuje z formy klasycznego studium, które tradycyjnie obejmuje całą twórczość pisarza. Krytyk dokonał zatem osobistego wyboru - analizuje prawdopodobnie tylko te teksty, które są mu bliskie ${ }^{5}$.

Rozprawa o Stasiuku składa się z czterech rozdziałów o intrygujących tytułach: 1) Auto-bio-grafia, 2) Bycie, 3) Niebycie, 4) Bycie Re-Aktywacja. W pierwszym z nich autor zdecydowanie odcina się od analizowania pisarstwa Stasiuka w ramach takich orientacji metodologicznych, jak postkolonializm, krytyka etyczna, geopoetyka czy kulturowa teoria literatury (deprecjonując je jako modne). Gleń podważa też zasadność stosowania w odniesieniu do prozy Stasiuka strategii (dość wąsko rozumianego) odbioru autobiograficznego. Przekonuje, że na „powieściową

${ }^{3}$ Dodatkowe informacje dotyczące serii znajdują się na stronie internetowej Wydawnictwa Uniwersytetu Łódzkiego. Zob. „Projekt: Egzystencja i Literatura”, https://wydawnictwo.uni.lodz.pl/serie/seria/projektegzystencja-i-literatura/ (dostęp: 10.01.2021).

${ }^{4}$ Zob. dyskusja z udziałem autorów publikacji z serii „Projekt: Egzystencja i Literatura”: Anny Legeżyńskiej, Tomasza Garbola i Adriana Glenia podczas 17. Opolskiej Jesieni Literackiej. „Życie i literatura: Hartwig, Miłosz, Stasiuk", https://www.youtube.com/watch?v=NwKQmPMU2BQ\&t=1501s (dostęp: 10.01.2021).

Warto także zwrócić uwagę na tytuły wydanych w serii prac (do tej pory ukazało się ich siedem). Przyjęto bowiem regułę opisywania analizowanej twórczości tylko jednym wyrazem: Agnieszka Kałowska, Witkacy. Etyka (2016), Marzena Woźniak-Łabieniec, Jarosław Marek Rymkiewicz. Metafizyka (2017), Maciej

Urbanowski, Stanisław Brzozowski. Nowoczesność (2017), Anna Legeżyńska, Julia Hartwig. Wdzięczność (2017), Tomasz Garbol, Czesław Miłosz. Los (2018), Agnieszka Kramkowska-Dąbrowska, Janusz Krasiński. Świadectwo (2020). Oddać jednym hasłem koncepcję interpretacyjną to niełatwe zadanie. Zasada narzuca lapidarny, być może nawet aforystyczny sposób formułowania myśli. Adrian Gleń ujawnia, że pierwotnie inaczej zamierzał zatytułować książkę: Żeby bardziej być, a najważniejszym powodem zmiany była właśnie koncepcja redakcyjna. Zob. Gleń, Andrzej Stasiuk. Istnienie, 14-15. Na komentarz zasługują też i wyraziste, korespondujące z treścią książek projekty okładek autorstwa Katarzyny Turkowskiej. Wykorzystane na nich fotografie pisarzy są zróżnicowane kolorystycznie; opatrzone charakterystycznym elementem graficznym - kropką, sygnalizującą perspektywę interpretacyjną: w wypadku Andrzeja Stasiuka (tak samo jak u Jarosława Marka Rymkiewicza i Stanisława Brzozowskiego) w ten sposób wyróżnione zostało oko. Przykładowo na zdjęciu Witkacego wyeksponowano usta, a u Julii Hartwig - kolczyk. W ten sposób grafiki twórczo uzupełniają tezy badawcze.

${ }^{5}$ W konsekwencji rozprawa nie obejmuje tak ważnych utworów, jak: Biały kruk (1995), Opowieści galicyjskie (1995), Dziewięć (1999) czy Dojczland (2007). Przede wszystkim jednak Adrian Gleń pomija oficjalny debiut Murów Hebronu (1992), który dla wielu krytyków jest wręcz kluczowy dla zrozumienia strategii pisarskiej Andrzeja Stasiuka. Ponadto w ogóle nie wspomina ani o jego wczesnych utworach poetyckich, ani dramatach. Warto też zaznaczyć, że Gleń eliminuje z horyzontu krytycznego książkę ewidentnie odwołującą się do formy autobiograficznej Jak zostałem pisarzem (próba autobiografii intelektualnej) (1998), a także przeprowadzoną przez Dorotę Wodecką rozmowę rzekę Życie to jednak strata jest (2015). Nie formułuję w tym miejscu zarzutu - zależy mi jednak na wyraźnym podkreśleniu stopnia subiektywności dokonanego przez krytyka wyboru. 
prawdę" utworów Stasiuka właściwiej jest spoglądać jako na „świadectwa jednostkowej wrażliwości i światooglądu, świadectwa wpisujące się zdecydowanie w charakter sztuki powieściowej, dla których mit i fantazmat należą do podstawowego instrumentarium"6.

Drugi rozdział, Bycie, organizuje kategoria „Wschodu”. Badacz w znacznej mierze odwołuje się do wydanej w 2014 roku książki Stasiuka o tym samym tytule, próbuje zdefiniować empatyczną i etyczną wizję pisarza. $Z$ jednej strony przedstawiony przez Stasiuka na planie geograficzno-historycznym Wschód jest, zdaniem Glenia, „wielką metonimią naszego lęku, archetypicznym obrazem zniewolenia i terroru” " Z drugiej zaś strony krytyk przekonuje, że Wschód jest „prazasadą Stasiukowego myślenia, źródłem osobistego i osobnego czucia rzeczywistości”'. Badacz jednocześnie sam odnajduje się w tych wyobrażeniach, doznaje tęsknoty za utraconą zasadą bycia, eksponuje tym samym bardzo osobisty wymiar metafory: „Dlatego widzę Wschód jako dopełnienie, wyprawę do podstawy własnego widzenia siebie i rzeczywistości. Dlatego zjeżdżam jeszcze na dół, «żółtymi» drogami, wybieram ścieżki, które chciałbym, aby przeprowadziły mnie przez Europę Środkową, znaną z Jadąc do Babadag, i niedostrzegalnie dla wszelkich pograniczników zawiały dopiero na Wschód"?

W tym samym, najobszerniejszym rozdziale Gleń omawia ważną w prozie Stasiuka problematykę światła, przedstawiając ją jako naczelną metaforykę istnienia. Zestawia też liczne odniesienia do treści religijnych oraz problemów metafizycznych. Przede wszystkim jednak wprzęga w proces interpretacji kluczowe elementy koncepcji Martina Heideggera: krytykę zachodniego modelu myślenia, zagrożenie techniką, które odrywa od porządku natury, przywiązanie do ziemi, posługiwanie się narzędziami, lęk przed śmiercią i utratą.

Rozdział Niebycie to analiza wydanego w 2012 roku zbioru opowiadań Grochów, w którym głównym tematem jest śmierć ważnych dla narratora osób (babki, przyjaciela, pisarza), a także bliskiego psa ${ }^{10}$. Uwzględniając prace Heideggera, opolski badacz odnosi się do mechanizmu zaprzeczania, „zagadywania" nieuchronnego końca życia. Wspominanie, przemieszczanie się, snucie opowieści to częste u Stasiuka sposoby wypierania świadomości kresu. Gleń jednak decyduje się w opozycji do myśli fryburskiego filozofa mocno zaakcentować opowiadanie się bohaterów Stasiuka po stronie życia, po stronie istnienia za wszelką cenę - podkreśla zdecydowany brak zgody na śmierć, na „ubywanie”.

Ostatni rozdział, Bycie Re-Aktywacja, jest kontynuacją wcześniejszych zagadnień. Krytyk wyraźnie ukazuje swoje filozoficzne inklinacje, budując wywód dotyczący takich kategorii, jak

\footnotetext{
${ }^{6}$ Gleń, Andrzej Stasiuk. Istnienie, 31.

${ }^{7}$ Gleń, 54.

${ }^{8}$ Gleń.

${ }^{9}$ Gleń, 56-57.

${ }^{10}$ Gleń pisze: „Wciąż potrzebna jest psia obecność, nawet owo «stygnące ciało» uczestniczy w przepływie ciepła, które stanowi wszak jedno z elementarnych imion istnienia”. Gleń, 149. Badacz z dużą uważnością przeanalizował problem «zwierzęcego istnienia» w prozie Stasiuka. Na uwagę zasługuje jeszcze taki fragment: „Na Wschodzie odkrywa się stop ludzkiego i zwierzęcego, twarze wrosłe w świat jak byliny, zakorzenione głęboko i samodzielnie w miejsca, od których nie można ich odłączyć, bez których miejsc tych nie podobna sobie w ogóle wyobrażać. Wobec tej nicości, wobec potworów historii, wobec rozpadającej się materii stają ludzie jakby bardziej będący. Istniejący wespół, wewnątrz, ubodzy i pokorny, silni mądrością ziemi”. Gleń, 74. Konkluzje Glenia obiecująco korespondują z próbami nieantropocentrycznego odczytania myśli Martina Heideggera. Ważna jest m.in. następująca publikacja: Magdalena Hoły-Łuczaj, Radykalny nonantropocentryzm. Martin Heidegger i ekologia głęboka (Warszawa: Wydawnictwa Uniwersytetu Warszawskiego, Rzeszów: Wyższa Szkoła Informatyki i Zarządzania, 2018).
} 
autentyczność, trwanie, nicość, pustka. Na uwagę zasługuje wskazany przez badacza ontologiczny stan trwania w dziele Stasiuka określony mianem „bezruchu”, a także konstatacje dotyczące relacji pomiędzy istnieniem i pamięcią. Interesujące są spostrzeżenia związane $z$ fotograficzną wrażliwością pisarza, która stanowi rodzaj pomostu pomiędzy minionym a obecnym: „Jak literatura przechowuje obrazy, tak i wszelkie «rysunki światłem» nieustannie pośredniczą w tym ruchu od «kiedyś» do «jest». Skuteczne odpomnienie gwarantuje każdy znak wizualny zdolny uruchomić obraz tkwiący u podstaw minionego doświadczenia"11. Gleń stara się udowodnić, że zmysłowy obraz poprzedza u Stasiuka wszelkie poznanie, a filtr fotograficznych (ale także malarskich) wyobrażeń gwarantuje głębię i prawdziwość istnienia oraz konstytuuje swoisty prywatny mit związany z wysiłkiem, by ocalić to, co materialne.

Chciałbym odnieść się w pierwszej kolejności do zagadnień związanych z autobiografizmem. Gleń zdecydowanie opowiada się za czytaniem prozy autora Murów Hebronu „bez biograficznych natręctw”. Co to właściwie oznacza? Zdaniem badacza, narracja Stasiuka, z wyraziście ukształtowanym „ja”, pozbawiona jest jednoznacznej identyfikacji. Ważne są więc takie kategorie jak „doznanie” i „spotkanie”, które wprawdzie mają swój początek w jednostkowym doświadczeniu (autentycznym przeżyciu), ale się w nim nie wyczerpują. W takim ujęciu źródłowe doświadczenie wskazuje raczej na metafizyczne uogólnienie, na bycie w ogóle. Nie wiąże się z formami autobiograficznymi, w których „życiopisanie” odwołuje się do konkretnego świadectwa. Dla Glenia odbiór autobiograficzny jest podejrzany, niekonsekwentny, niepewny. Autentyczność ${ }^{12}$ pisarstwa Stasiuka proponuje zrozumieć na podstawie samej konwencji pisarskiej oraz uwierzytelniających strategii stosowanych przez autora ${ }^{13}$. Przekonuje, że centrum narracji Stasiuka: „nie jest zachłanne czy kokieteryjne autorskie ego, domagające się wyznawców, lecz czułe i sylleptyczne «ja», które odsuwając i zawieszając kwestię identyfikacji z autorem, nie uśmierca go jednak i uzyskuje tym samym legitymację do snucia swoich - wierzymy dzięki temu właśnie, że autentycznych - historii i refleksji z rozpryskującego się życia" ${ }^{14}$. Badacz niestety nie rozwija istotnej myśli dotyczącej sylleptyczności tekstu literackiego. Można powiedzieć, że wywód dotyczący autobiografizmu został ucięty w najciekawszym momencie.

${ }^{11} \mathrm{Glen}$, Andrzej Stasiuk. Istnienie, 181. Warto krótko skomentować istotne dla zrozumienia wywodu autora, nieoczywiste i specyficznie nacechowane kulturowo pojęcie „odpomnienia”. Prawdopodobnie jako pierwszy tego terminu użył Cyprian Kamil Norwid w poemacie A Dorio ad Phrygium (1872), natomiast do popularyzacji pojęcia przyczyniły się w znacznej mierze publikacje Huberta Orłowskiego. „Odpomnienie” oznacza proces zbliżony do anamnezy (gr. anamnesis), czyli przywoływania ukrytych przed podmiotem wspomnień. „Odpominanie” nie dotyczy jednak treści wrodzonych - jak w Platońskiej teorii poznania - ale nabytych. W odróżnieniu od wywiadu lekarskiego, czyli anamnezy medycznej, nie stanowi wyniku „zewnętrznej” wobec podmiotu diagnozy, lecz jest rezultatem pracy indywidualnej. Kojarzona także z eucharystią chrześcijańską anamneza to „czynienie pamiątki”, a zatem upamiętnienie rzeczy znanych - „odpominanie” to wydobycie treści samemu podmiotowi niewiadomych. Omawianego zjawiska nie można również wiązać z procesem „przypominania sobie”, czyli odzyskiwania treści, o których podmiot wie, że już istniały w jego pamięci. „Odpominanie” dotyczy bowiem tych obszarów pamięci, o których istnieniu podmiot zapomniał - można zatem powiedzieć, że początkiem procesu „odpominania” jest moment przypomnienia sobie o tym zapomnieniu. Zob. Przemysław Czapliński, Kornelia Kończal, „Odpominanie”, w Modi memorandi. Leksykon kultury pamięci, red. Magdalena Saryusz-Wolska, Robert Traba, współpraca Joanna Kalicka (Warszawa: Wydawnictwo Naukowe Scholar, 2014), 301.

${ }^{12}$ Interesujące byłoby rozszerzenie tak ważnej dla Glenia (i wykorzystywanej także w innych jego pracach) kategorii „autentyczności” o ustalenia Olgi Szmidt, która w swoich badaniach nad autentycznością w kulturze XXI wieku postanowiła odsunąć na dalszy plan prace Charlesa Taylora, Theodora Adorna, Martina Heideggera czy Sørena Kierkegaarda, by skupić się na koncepcjach takich filozofów, jak: Jean-Jacques Rousseau, Henry David Thoreau czy Marshall Berman. Zob. Olga Szmidt, Autentyczność: stan krytyczny. Problem autentyczności w kulturze XXI wieku (Kraków: Universitas, 2019).

${ }^{13}$ Gleń, Andrzej Stasiuk. Istnienie, 42-47.

${ }^{14}$ Gleń, 50 . 
W tym kontekście aktualne wciąż pozostają zastrzeżenia, które Piotr Sobolczyk sformułował w recenzji pracy Glenia poświęconej Mironowi Białoszewskiemu ${ }^{15}$. Zwrócił uwagę, że autor, odrzucając metodę autobiograficzną, tak naprawdę rozumie ją dość wąsko, przede wszystkim w nawiązaniu do Paktu autobiograficznego Philippe'a Lejeune'a. Sobolczyk sygnalizuje konieczność uwzględnienia innych, nowszych metodologii autobiograficznych, odwołując się właśnie do zaproponowanej przez Ryszarda Nycza „sylleptycznej” koncepcji podmiotowości, a ściślej sylleptycznego tropu „ja” w tekście ${ }^{16}$. Nycz uznał, że „ja” sylleptyczne funkcjonuje równocześnie na dwa odmienne sposoby - zarówno jako prawdziwe, empiryczne, autentyczne, jak i zmyślone, tekstowe, fikcyjnopowieściowe ${ }^{17}$. Elżbieta Winiecka konkluduje: „Zachowanie jednorodnej, konsekwentnie jednopłaszczyznowej perspektywy jest bowiem praktycznie niemożliwe w literaturze, która z założenia wprowadza rozziew pomiędzy «ja» wypowiadającym a «ja» wypowiadanym, «ja» empirycznym a «ja» tekstowym. Ale to właśnie stworzenie sugestii owej jednolitości pisaniowo-przeżyciowej jest celem pisarza umieszczającego się w samym centrum opisywanych zdarzeń"18. Adrian Gleń, łącząc więc narrację Stasiuka z sylleptycznym „ja”, tak naprawdę umieszcza tę twórczość w centrum metodologicznej dyskusji związanej z autobiografizmem.

Piotr Sobolczyk daje ponadto do zrozumienia, że wyraźna opozycja autobiografizm - hermeneutyka jest nieuzasadniona - i to zarówno w ujęciu Schleiermacherowskim, jak i w dużo późniejszych, dwudziestowiecznych koncepcjach. Krytyk odnotowuje eklektyczny, „wchłaniający" charakter hermeneutyki. Podkreśla chociażby wpływ metody autobiograficznej na rozwój myśli Paula Ricoeura ${ }^{19}$. Adrian Gleń, tak zdecydowanie dyskredytując „biograficzne natręctwa", jednocześnie przemilcza więc znaczącą rolę, jaką odegrały badania nad biografistyką w procesie kształtowania się metodologii hermeneutycznej ${ }^{20}$.

\footnotetext{
${ }^{15}$ Adrian Gleń, „W tej latarni...”. Późna twórczość Mirona Białoszewskiego w perspektywie hermeneutycznej (Opole: Wydawnictwo Uniwersytetu Opolskiego, 2004).

${ }^{16}$ Piotr Sobolczyk, „Hermeneutyka tak, ale jaka?”, Teksty Drugie 1/2 (2006): 152-153.

${ }^{17}$ Ryszard Nycz, Język modernizmu. Prolegomena historycznoliterackie (Toruń: Wydawnictwo Naukowe Uniwersytetu Mikołaja Kopernika, 2013), 114.

${ }^{18}$ Elżbieta Winiecka, „O sylleptyczności tekstu literackiego”, Pamiętnik Literacki 4 (2004): 146.

${ }^{19}$ Sobolczyk, „Hermeneutyka tak, ale jaka?”: 154. Zmagania Paula Ricoeura z badaniami nad autobiografią szczegółowo przeanalizowała Zofia Mitosek. Zob. Zofia Mitosek, „Hermeneuta i autobiografia”, Teksty Drugie 3 (2002): 137-151.

${ }^{20}$ Anna Legeżyńska niedawno odświeżyła tę problematykę w kontekście rozwoju polskich badań literaturoznawczych. Zob. Anna Legeżyńska, „Wystarczy mocno i wytrwale zastanawiać się nad jednym życiem...». Biografistyka jako hermeneutyczne wyzwanie”, Teksty Drugie 1 (2019): 13-27. Warto przy tej okazji przywołać chociażby kluczową dla tradycji hermeneutycznej postać Wilhelma Diltheya. W procesie kształtowania się jego „filozofii życia” ważne miejsce zajmowała bowiem koncepcja badania biografii pojedynczej osoby. Listy, dokumenty, dzieła literackie wybitnych jednostek stanowiły dla myśliciela szansę na zobiektywizowanie wytworów ich życia duchowego, a tym samym poznanie możliwości człowieka. Dilthey stopniowo jednak rozszerzał zakres obiektywizacji ludzkiego życia, skupiając się na badaniu dziejów, na refleksji nad procesem historycznym. Hermeneutyczny charakter poszukiwania wiedzy o człowieku sprawił, że Dilthey postrzegał historyczne przejawy ludzkiego życia jak teksty pisane. Przyjął założenie, że wytwory człowieka wyrażają jego życie, a tym samym dają wgląd w jego sprawy. Hermeneutyczne rozumienie w koncepcji Diltheya pozwala na wyjście poza indywidualne ograniczenia, z zasady nie dochodzi jednak do ostatecznych rezultatów, czyli poznania człowieka jako całości (są to bowiem założenia odrzuconej przez filozofia metafizyki). Dilthey postrzega człowieka z perspektywy działania, a nie kontemplacji. Rozumienie w tym ujęciu zawsze ma granice. Zob. Włodzimierz Lorenc, Hermeneutyczne koncepcje człowieka 2. Dilthey, Misch, Bollnow (Warszawa: Wydawnictwo Naukowe „Scholar”, 2008), 78-85. Należy jednocześnie pamiętać, że filozofię Diltheya trudno uznać za dopracowaną. Myśliciel często zmieniał swoje poglądy - co podkreślali jego uczniowie - w zależności od kontekstu te same wypowiedzi mogą mieć więc różny sens. Zob. Włodzimierz Lorenc, Filozofia hermeneutyczna. Inspiracje, klasycy, radykalizacje (Warszawa: Wydawnictwa Uniwersytetu Warszawskiego, 2019), 61.
} 
Zagadnienia dotyczące autobiografizmu wiążą się także z innym tematem szczególnie ważnym w rozprawie - podejściem autora do dyskursu krytycznoliterackiego. W prologu do książki pisze:

Krytyk wypowiadający pochwałę literatury może wydawać się zrazu postacią co najmniej dwuznaczną albo zgoła fałszywą. Przede wszystkim bowiem ryzykuje: utratą zaufania (jeśli na takowe zasłużył), rezygnacją z własnego „znawstwa” (do czego odsyła i obliguje łacińskie źródło, criticere, tego ginącego już dzisiaj zawodu). Jego zachwyt budzi niedobre skojarzenia, sceptyczny półuśmiech, w najlepszym razie - niedowierzanie. Oto dotychczas chronił się za parawanem, np. „obiektywności” czy „specjalistycznego widzenia”, teraz staje nagi, a nagość jego rodzi nagłe zażenowanie przy jednoczesnym grymasie podejrzliwości: ejże, czy to nie ten, który ważył sądy i racje, starannie dobierał język, dokonywał nieustannych przekładów, upierał się przy tym, że tu, a nie gdzie indziej, bije serce jakiegoś dzieła, zachłannie ściskał legitymację jedynego odkrywcy tajemnicy literatury, z godną podziwu powściągliwością i dystynkcją wymierzał cenzurki i razy? A teraz twierdzi, że się odkrył, zrzucił płaszcz konwencji, jest naraz autentyczny, prawdziwy ${ }^{21}$ ?

Gleń nie obawia się fascynacji twórczością Stasiuka, a wręcz specjalnie uwydatnia własną wdzięczność wobec pisarza. W konsekwencji nie odnotowuje dużego wpływu na autora Dukli twórczości Jeana-Paula Sartre’a, Samuela Becketta, Stanisława Grzesiuka, Marka Hłaski czy Edwarda Stachury ${ }^{22}$. Według opolskiego krytyka, Stasiuk pisze „z niezrównaną współcześnie literacką emfazą, operując frazą całkowicie oryginalną"23. Zamiast więc wskazywać na wyraźne inspiracje Stasiuka, badacz zdecydowanie woli wspominać o „literackich sprzymierzeńcach”. Pisze z pełnym przekonaniem: „Stasiuka umieszczać trzeba koniecznie wśród tych pisarzy, którzy - jak dla przykładu Schulz, Miłosz, Szczepański czy Białoszewski - stoją po stronie tego, co kalekie, ułomne, represjonowane, wykluczane i wyrzucane poza nawias wyrażalności. I w tej mierze jego wizja jest głęboko humanistyczna, empatyczna i etyczna - po prostu i na elementarnym poziomie"24. W innym miejscu Gleń wyznaje: „Tak, zapewne gdzieś pomiędzy Schulzowsko-Miłoszową liturgią metafizyczną a kpiarskim kabaretem Gombrowicza i łagodną nostalgią Haupta sytuują się filozoficzno-literackie wizje autora Opowieści galicyjskich"25. Cóż, takie zestawienia oceniam po prostu jako przesadne.

Adrianowi Gleniowi nie przeszkadza ponadto powtarzanie przez beskidzkiego pisarza tych samych metafor, nieprzyzwoicie podobnych do siebie podróżniczych relacji, a nawet banalizowanie filozoficznych koncepcji, na które się powołuje. Dokonane przez krytyka odczytanie utworów Stasiuka jest pełne powagi i - jak sam badacz to ujął - „zawierzenia” pisarzowi. Eksponuje wyłącznie oryginalność i autentyczność omawianych utworów: „Kto wie, czy jednym z najświetniejszych pisarzy - najczulszych, najuważniejszych - w polskiej prozie współczesnej nie jest właśnie Andrzej Stasiuk: strażnik bycia, który pisze, idąc ze śmiercią pod ramię, z której i przeciw której jego pisanie wyrasta" 26 .

\footnotetext{
${ }^{21}$ Gleń, Andrzej Stasiuk. Istnienie, 10-11.

${ }^{22} \mathrm{~W}$ jednym miejscu Adrian Gleń powołuje się tylko na pracę Elżbiety Dutki, która zaznacza w przypisie, że Stasiuk bywał opisywany m.in. jako spadkobierca legendy Marka Hłaski i Edwarda Stachury. Zob. Elżbieta Dutka, „ «Słowiańskie on the road» - o Europie «zwanej Srodkową» w prozie Andrzeja Stasiuka”, Fraza 4 (2007): 170.

${ }^{23}$ Gleń, Andrzej Stasiuk. Istnienie, 24.

${ }^{24}$ Gleń, 52 .

${ }^{25}$ Gleń, 95 .

${ }^{26}$ Gleń, 14.
} 
Zachwyt Stasiukowym pisarstwem skutkuje także bezkompromisowością, a nawet pewną bezwzględnością badacza wobec opinii innych krytyków: „Sporą dozą metodologicznej ignorancji wykazuje się zwłaszcza Piotr Majewski, który nie bacząc na charakter literackiego przedstawiania, nie waha się skonkludować, że proza Stasiuka wpisuje się bez reszty w generalizujący dyskurs etniczny, oparty na stereotypizacji obcego [...] $]^{27 ”}$. W innym miejscu komentuje: „Konkluzja tekstu Skórczewskiego zdradza, że jej autor za wszelką cenę chce udowodnić prawdziwość... przyjętej przez siebie metodologii. W zamknięciu swojego ciekawego studium używa spetryfikowanych formuł stanowiących ideową podbudowę myśli postkolonialnej, nie troszcząc się zupełnie o jej zgodność z literackimi świadectwami”28. Gleń wyraźnie dystansuje się od myśli postkolonialnej, ukazując Stasiukową podróż na Wschód jako „doświadczenie głębokiego poczucia bycia wewnątrz rzeczywistości”29 (przeciwstawione w znacznym stopniu neurotycznej, nieautentycznej egzystencji człowieka Zachodu).

Z pewnością ważnym źródłem inspiracji jest dla Glenia „krytyka identyfikująca się” Georges'a Pouleta. Ten przedstawiciel szkoły genewskiej, będący z kolei pod dużym wpływem refleksji teoretycznych Marcela Prousta ${ }^{30}$, przekonuje, że największym wyzwaniem dla krytyka jest zdanie relacji z własnego zachwytu. Według Pouleta, krytyk powinien skomponować tekst, który byłby „duchową kopią analizowanego dzieła” - co jest możliwe tylko wówczas, gdy nastąpi „całkowite przeniesienie jednego świata umysłu w drugi” ${ }^{1}$. W moim przekonaniu, koncepcja Pouleta prowadzi Glenia do pastiszu ${ }^{32}$. Badacz tak opisuje własną podróż do „ziemi pisarza":

Gdzieś przed Zborovem zaczęły stukać zawory i musiałem się zatrzymać, aby dolać oleju do zmęczonego, wysłużonego lanosa. Otworzyłem maskę, zalałem silnik. I wspiąwszy się na kamienny murek, z dyndającymi stopami, zapaliłem papierosa. Może miałem tutaj przyjechać i doświadczyć tej doskonałej wolności? Czy to jest genius loci tej ziemi?

\footnotetext{
${ }^{27}$ Gleń, 34. Badacz odnosi się do tez zawartych w artykule: Piotr Majewski, „Przeglądanie się w Cyganie: obraz Innego w prozie Andrzeja Stasiuka”, Sprawy Narodowościowe 32 (2008): 151-163.

${ }^{28}$ Gleń, Andrzej Stasiuk. Istnienie, 38. Tu Adrian Gleń polemizuje z tekstem: Dariusz Skórczewski, „Kompleks(y) środkowego Europejczyka", Opcje 2 (2008): 10-11.

${ }^{29} \mathrm{Gleń}$, Andrzej Stasiuk. Istnienie, 39.

${ }^{30}$ Zob. Georges Poulet, „Krytyka identyfikująca się”, tłum. Judyta Zbierska-Mościcka, w Szkoła Genewska w krytyce. Antologia, wybór Henryk Chudaki i in., przedmowa Maciej Żurowski (Warszawa: PWN, 1998), 164-169. Adrian Gleń, nawiązując w pracy poświęconej twórczości Juliana Kornhausera do Heideggerowskiej zasady „słuchania dzieła”, wyraźnie podkreślił, że postulat krytyki empatycznej zawarty w programie szkoły genewskiej jest także nieodłącznym składnikiem krytyki hermeneutycznej. Zob. Adrian Gleń, „Marzenie, które czyni poetą"... Autentyczność i empatia w dziele literackim Juliana Kornhausera (Kraków: Universitas, 2013), 169.

${ }^{31}$ Georges Poulet, „Krytyka identyfikująca się”, 159.

${ }^{32}$ Pastisz wiąże się z bardzo różnymi ocenami - od niechęci, przez neutralność, po fascynację. Emocje, które wzbudza, zależą w znacznej mierze od tego, jak jest definiowany i jakie funkcje są mu przypisywane, może być bowiem traktowany jako gatunek, odmiana stylizacji lub kategoria estetyczna. Zob. Artur Hellich, „Jak rozpoznać pastisz (i odróżnić go od parodii)?”, Zagadnienia Rodzajów Literackich 2 (2014): 28. Dla Pouleta to raczej nie pastisz stanowi punkt dojścia „aktu krytycznego”; taki „gest przejęty”, czyli naśladowanie, imitowanie stylu pisarza, nie jest jeszcze właściwą krytyką. Badacz pisze: „Utożsamienie się z tym, co czytamy, sprawia, że nagle jesteśmy w niezwykłym świecie, gdzie wszystko jest nowe i zarazem robi wrażenie autentyczności. [...] Pastiszowanie autora jest naśladowaniem tego, co błahe, i tego, co istotne". Poulet, „Krytyka identyfikująca się”, 166-167. Kluczem dla Pouleta jest więc znalezienie drogi do miejsc istotnych. "Powołując się na „krytykę tematyczną” Marcela Prousta, podkreśla znaczenie „improwizowanej pamięci”, która pozwala przypominać sobie „tematy wspólne”, a pomijać „efekty drugorzędne”. Zob. Poulet, „Krytyka identyfikująca się", 167-169.
} 
Więc siedziałem i paliłem. Aż pojawili się oni - cygańska rodzina, z trudną do zliczenia dzieciarnią. Szli przez środek tej bocznej uliczki (na wysokości sklepu, gdzie można zapłacić w złotówkach, ponoć jedynego, w którym naszą walutę chce się komuś później wozić przez granicę), jak zawsze głośni i jak zawsze na niewiele się oglądający.

A potem stary żydowski cmentarz. Uprzejmy Słowak ośmielił mnie do otworzenia głównej bramy... butem. Wahałem się chwilę. Ale przecież chciałem z bliska odmówić mój cudzoziemski „kadisz”. Wobec połamanych i zarośniętych - jak zawsze, jak wszędzie - macew, z których nie sposób czegokolwiek odczytać.

Moment rozbuchanej radości cygańskiej familii i wiekuisty rozkład kamiennych śladów niemej pamięci. Trudno o lepszy uścisk, zapasy teraz i było ${ }^{33}$.

Nagromadzenie w krótkim fragmencie tak wielu elementów stylu pisarza może dziwić. Otrzymujemy Stasiuka zwielokrotnionego, a może raczej skondensowanego, co w mojej ocenie wywołuje wręcz niezamierzony efekt komiczny ${ }^{34}$. To osłabia odbiór wywodu. Opowieść Glenia jest także niekonsekwentna i dość zaskakująca. Gwałtownie przechodzi od zabarwionego literacko i - co należy wyeksponować - osobistego, autobiograficznego rejestru, czyli prób wniknięcia we frazę Stasiuka, do dyskursu naukowego: specjalistycznych terminów, rzeczowego przywoływania tez innych badaczy, ostrej polemiki. Nagle czułość zamienia się w naukową ocenę. Tę praktykę dobrze oddaje tytuł króciutkiego, jednostronicowego podsumowania rozprawy: Wejście i wyjście. I wejście. I tak właśnie się czułem - zapraszany do bardzo intymnego świata, następnie oficjalnym tonem dyskretnie wypraszany, a po dłuższej chwili nieoczekiwanie zasypywany kolejnymi zwierzeniami. Zaskoczenie, konsternacja... Skończywszy książkę, byłem nieco zmieszany. Pozostało we mnie wrażenie, że autor jest otwarty, wrażliwy, bezpośredni, a jednocześnie ostry w sądach i despotyczny. Wspomniane podsumowanie książki stanowi właściwie kilkuzdaniowy komentarz do obszernego cytatu z Jadąc do Babadag Stasiuka. Myśl Glenia, która wieńczy rozprawę, przywołam w całości:

Tak, bo prawdziwa śmierć powinna naśladować życie. - To zdanie przepisane od Stasiuka musi tę książkę zamknąć.

Tak to sobie wyobraziłem już dawno.

I tak właśnie $\mathrm{JEST}^{35}$.

Tyle w tej krótkiej wypowiedzi dominacji: prawdziwa, powinna, musi, tak właśnie jest... To fascynacja prozą Stasiuka sprawia, że Adrian Gleń jest tak zaborczy, kategoryczny

\footnotetext{
${ }^{33}$ Gleń, Andrzej Stasiuk. Istnienie, 5-6.

${ }^{34}$ Taki efekt wybija rzecz jasna $z$ hermeneutycznego trybu lektury i odsyłają w obszary opisanego przez Ryszarda Nycza sporu o charakter postmodernizmu, czyli zakresu odziaływania dwóch zasad kreowania artystycznej formy: parodii i pastiszu. Zob. Ryszard Nycz, Tekstowy świat. Poststrukturalizm a wiedza o literaturze (Warszawa: IBL, 1993), 184-188.

${ }^{35}$ Gleń, Andrzej Stasiuk. Istnienie, 201.
} 
w swoich ocenach i ustaleniach. Zachwyt pobudza badacza do fragmentarycznego „pisania Stasiukiem", imitowania jego stylu, konstruowania pewnej narracyjnej wspólnoty z pisarzem ${ }^{36}$.

Jak już wspominałem, perspektywę, z której badacz analizuje prozę Stasiuka, w dużym stopniu wyznaczają problemy podjęte przez Martina Heideggera. I w tym kontekście znowu istotny wydaje mi się język opolskiego badacza ${ }^{37}$. Sam wywód naukowy rozprawy, który skontrastowałem już z gestem powtórzenia frazy Stasiuka, także nie jest w moim przekonaniu jednolity. W wielu fragmentach dyskurs akademicki zmienia charakter i staje się wyjątkowo metaforyczny. Fragmenty te można odczytać jako nawiązania - intencjonalne lub nieintencjonalne - do stylu autora Znaków drogi (oraz jego kontynuatorów) ${ }^{38}$.

${ }^{36}$ Innym, interesującym sposobem uprawiania krytyki literackiej pod wpływem fascynacji analizowaną twórczością jest ujęcie Richarda Rorty'ego (filozofa - co warto odnotować - krytycznie nawiązującego z perspektywy neopragmatyzmu także do hermeneutycznej koncepcji Heideggera). W eseju Kariera pragmatysty, dyskutując z wprowadzonym przez Umberta Eco rozróżnieniem między użyciem i interpretacją, Rorty przekonuje, że tekst dostarcza bodźców, dzięki którym czytelnik (a tym samym krytyk) „z większą lub mniejszą trudnością potrafi przekonać siebie i innych do tego, co od samego początku miał ochotę powiedzieć na temat tego tekstu”. Richard Rorty, „Kariera pragmatysty”, tłum. Tomasz Biedron, w Umberto Eco, Interpretacja i nadinterpretacja (Kraków: Wydawnictwo Znak, 1996), 102. Rorty podważa zatem model krytyki literackiej odwołujący się do metafory „wewnętrznej spójności tekstu” zaproponowanej przez Eco. Zdaniem pragmatysty dzieło literackie nie może powiedzieć tego, co samo chce powiedzieć. Dlaczego jednak odwołuję się akurat do tej polemiki Richarda Rorty’ego z uwikłanym w koło hermeneutyczne Umbertem Eco? Otóż w przywołanym eseju pojawia się kluczowa dla Adriana Glenia kategoria fascynacji. Rorty stoi na stanowisku, że o fascynacji (i przekonaniu) przesądzają potrzeby i cele osób, które dają się zafascynować. W ten sposób rozróżnienie między użyciem i interpretacją zostaje zastąpione wieloma zróżnicowanymi „użytkami”, jakie czytelnicy (krytycy) czynią z tekstu. Najciekawsza wydaje mi się jednak konkluzja eseju, w której Rorty przedstawia kolejną opozycję: metodyczne i natchnione odczytywanie tekstów. Metodyczna krytyka wyzuta jest z autentycznego zaangażowania. Ten tryb czytania nie zmienia z góry założonych celów. Krytyka natchniona jest natomiast rezultatem spotkania $\mathrm{z}$ autorem, postacią, fabułą czy strofą. Wpływa na wyobrażenie krytyka o sobie. Utwór zmienia krytyka, zmieniając jego cele względem ludzi, rzeczy, tekstów napotykanych w dalszym ciągu życia. Nie ma to jednak wiele wspólnego z dążeniem do odróżniania rzeczywistości od pozoru. Zob. Rorty, „Kariera pragmatysty”, 96-107.

${ }^{37}$ Przywiązując tak dużą wagę do warstwy językowej rozprawy Adriana Glenia, uwzględniam tym samym jego metodologiczne inklinacje. Martin Heidegger jest z pewnością tym filozofem, który właśnie z języka uczynił podstawowy problem hermeneutyki. (Nie można jednocześnie zapominać o ewolucji namysłu autora Bycia i czasu nad problemem języka - po tzw. zwrocie filozof znacząco wykroczył poza ramy stanowiska hermeneutycznego.) Przypomnijmy: Heidegger powiązał język ze swoją koncepcją rozumienia, argumentując, że nie jest możliwe ludzkie bytowanie, nie jest możliwe bycie-w-świecie, które wykraczałoby poza język. Warto podkreślić, że to stanowisko Heideggera w zasadniczy sposób wpłynęło na rozwój hermeneutyki, a szczególnie na myśl Hansa-Georga Gadamera, który dowodził, że nie panujemy nad językiem, lecz przynależymy do niego. W związku z tym prawdziwa rozmowa nie występuje, zdaniem autora Prawdy i metody, gdy ją „prowadzimy”, lecz gdy się w nią „wdajemy”, gdy ona sama nas prowadzi. Dla Gadamera zwrot hermeneutyczny w filozofii jest zatem równoznaczny ze zwrotem lingwistycznym. Zob. Michał Januszkiewicz, W poszukiwaniu sensu. Phronesis i hermeneutyka (Poznań: Wydawnictwo Naukowe UAM, 2016), 86-91.

${ }^{38}$ Wbrew założeniom serii „Projekt: Egzystencja i Literatura” publikacja Andrzej Stasiuk. Istnienie nie należy wcale do przystępnych. Tak naprawdę w warstwie językowej rozprawy zaobserwować można trzy rozwiązania stylistyczne: tradycyjny dyskurs akademicki podzielony z jednej strony dość hermetycznymi fragmentami nawiązującymi do filozoficznego języka Heideggera, z drugiej zaś - wyraźnie odznaczające się autobiograficznym charakterem próby powtórzenia poetyki Stasiuka. Momentami można się nawet zastanawiać, czy koncepcja „duchowej kopii” Pouleta w różnych miejscach pracy Glenia nie odwołuje się raz do jednego, a innym razem do drugiego „świata umysłu”. Zamiast jednak próbować arbitralnie rozstrzygać tę kwestię, wolę przywołać związane z zagadnieniem „metaforyzowania” dyskursu naukowego istotne ustalenia Heideggera: do (autentycznego) języka można podążać, wykorzystując dwie (sąsiadujące ze sobą) drogi: myślenia i poetyzowania. Myślenie jest charakterystyczne dla filozofa, a poetyzowanie - oczywiście dla poety. Myślenie w ujęciu Heideggera unika jednak kategorii metafizycznych, logicznych czy naukowych, tym samym zbliża się do poezji. Takie „myślenie poetyzujące” nie oznacza dowolności - „ścisłość” pojmowana jest niemetafizycznie i z punktu widzenia nauki staje się „nie do pomyślenia”. Zob. Michał Januszkiewicz, W-koło hermeneutyki literackiej (Warszawa: PWN, 2007), 45. Można się jeszcze zastanawiać, czy wpływu na język rozprawy Glenia nie ma fakt, że autor jest także poetą, a więc „droga poetyzowania” może stanowić atrakcyjny kierunek wyrażania treści umykających typowo akademickiemu dyskursowi. Nie zamierzam jednak rozstrzygać tego problemu. Nawiasem mówiąc, taki splot języka krytycznoliterackiego i poetyckiego Adrian Gleń sam zamierzał przeanalizować w pracy poświęconej Julianowi Kornhauserowi. Zrezygnował jednak z takiego podejścia - postanowił „zawierzyć” Kornhauserowi, który (jako krytyk) przestrzegał przed komplementarnym, dopełniającym się traktowaniem poezji i krytyki jednego autora. Zob. Gleń, „Marzenie, które czyni poetą”... Autentyczność i empatia w dziele literackim Juliana Kornhausera, 35-37. 
Z językiem fryburskiego filozofa kojarzyć się może dodatkowo często stosowany przez Glenia zabieg polegający na wykorzystywaniu dywizu do konstruowania nowych terminów. Oto kilka przykładów: „nie-i-widzialność”, „przed-stawianie”, „nic-nie-robienie”, „pisanie-ku-życiu”, „re-aktywacja”, „teraz-trwanie”. Praktyki tego typu bywają i uzasadnione, i potrzebne (zwłaszcza w tradycji hermeneutycznej). Stosowane jednak w dużym nagromadzeniu tracą moc, w rezultacie czego wydają się zbędne ${ }^{39}$. Te neologizmy, te złożone konstrukcje językowe nie tyle budują napięcie, odkrywając przed czytelnikiem świeże obszary znaczeniowe, ile po prostu dobitnie wskazują krąg inspiracji. Jak zaklęcia przenoszą w pobliże źródła ${ }^{40}$.

Chciałbym jednak podkreślić, że nie jest moim zamiarem przesadne eksponowanie niespójności czy też pewnych niekonsekwencji w warstwie stylistycznej pracy. O wiele istotniejsze wydaje mi się zwrócenie uwagi na trudności i wyzwania metodologiczne związane z obecnymi próbami uprawiania krytyki identyfikującej się, a także implementowania Heideggerowskich rozstrzygnięć w badaniach literackich. Uważam po prostu, że analiza języka rozprawy umożliwia omówienie wielu kluczowych zagadnień podjętych przez badacza.

Adrian Gleń najczęściej zbliża się do poetyckiego stylu Martina Heideggera, gdy eksponuje w twórczości Stasiuka potrzebę transcendencji, przekraczania tego, co sensualne i empiryczne:

Dyskrecja jako rewers pewności, która rodzi jedynie hałas i chaos (discretio wszak przeciwstawia się discrepatio - 'nierównemu brzmieniu', 'pierwotnej niezgodności'), otwierająca przestrzeń tego, co w tekście nie poddaje się metodycznej eksplikacji. Właśnie w to, co dyskretne w utworze - ewokującym metafizyczną perspektywę - powinniśmy się wsłuchiwać najbaczniej. Usilnie, używając przede wszystkim empatii. Dopiero to, co niejasne, niepewne z utworu daje do myślenia. Nie-jasne, w którym mogę zobaczyć kawałek rzeczywistości niechcącej pozostać w swoich granicach, kiedy widzę bezradność poznawczą mówiącego podmiotu, przyznającego się, że jego język kapituluje w obliczu tajemnicy, że tajemnica jest i pozostanie jakimś pasem transmisyjnym jego podróży, pisania i rozumienia albo że rodzące się w swoim naporze siatki obrazów nie wyczerpują się tylko w tym, co z mniejszym lub większym popisem próbują reprezentować. Coś takiego zwłaszcza każe czytelnikowi zatrzymać się i odpowiedziećt ${ }^{41}$.

Krzysztof Michalski akcentuje związki Bycia i czasu z myśleniem religijnym, wskazując (za Erichem Auerbachem) na „styl biblijny” dzieła ${ }^{42}$. Według niektórych badaczy prace Martina Heideggera mają więcej wspólnego z mitem, poezją czy religijną medytacją niż z tradycyjnym wywodem filozoficznym. Przykładowo dla Waltera Strolza Heidegger jest myślicielem medytatywnym. John D. Caputo czy Otto Pöggeler podkreślają zaś obecność w refleksji fryburskiego myśliciela elementów mistycznych. Odnotować należy także próby łączenia jego koncepcji z azjatycką tradycją

\footnotetext{
${ }^{39}$ Dobrym przykładem na to, że można przeprowadzić konsekwentną analizę hermeneutyczną bez nadużywania tej maniery językowej jest niedawno wydana rozprawa Marka Bernackiego dotycząca twórczości Czesława Miłosza: Marek Bernacki, Tropienie Miłosza. Hermeneutyczna „bio-grafia” Poety (Kraków: Universitas, 2019).

${ }^{40} \mathrm{Na}$ podobnej zasadzie bardzo często wykorzystywany jest przez autora nawias: „z(a)nik”, ,(o)pisanie”, „(p)o(d) glądanie”, „(nie)obecność”, „o(d)żyw(i)ająca (się) świadomość”. Zabieg jednak nie zaskakuje - wykorzystywanie tych znaków pisarskich do tworzenia neologizmów jest bowiem w obecnym dyskursie humanistycznym niezwykle popularny, a może nawet nadużywany.

${ }^{41}$ Gleń, Andrzej Stasiuk. Istnienie, 72.

${ }^{42}$ Krzysztof Michalski, Heidegger i filozofia wspótczesna (Warszawa: Państwowy Instytut Wydawniczy, 1978), 46-48.
} 
filozoficzną ${ }^{43}$. Odnoszę zatem wrażenie, że nawiązania do stylu Heideggera umożliwiają Gleniowi eksponowanie w prozie Stasiuka „ogromnego ładunku metafizyki i religijności”44.

Według mnie już od oficjalnego debiutu tomu opowiadań Murów Hebronu (1992) w prozie Stasiuka zaobserwować można rozwój problematyki związanej z religijnością ${ }^{45}$. Na poziomie najbardziej podstawowym są to zazwyczaj odniesienia do wątków biblijnych, ale pojawiają się także - choć zdecydowanie rzadziej - nawiązania do wschodniej tradycji religijnej. Istnieją podstawy, żeby wiązać tematykę religijną w twórczości beskidzkiego pisarza z kontrkulturową fascynacją duchowością ${ }^{46}$. Warto też wyraźnie podkreślić, że bohater Stasiuka zdecydowanie zdradza niechęć do zinstytucjonalizowanej religii.

W prozie Stasiuka dostrzegam wiele motywów odwołujących się do mistyki, na przykład zjawisko zatrzymania, zakwestionowania czasu i udział bohaterów w swoistym, wiecznym „teraz” albo silne, iluminacyjne wręcz uczucie, że otaczająca rzeczywistość jest jedynie złudzeniem, bytem pozornym ${ }^{47}$. I Adrian Gleń zwraca na to uwagę, tak pisząc o Stasiukowym byciu w drodze: „Podróż na wschód jest tedy niczym mistyczne doświadczenie spustoszenia, ogołocenia" ${ }^{48}$.

Podobnie jak wielu mistyków bohaterowie z książek Stasiuka posługują się językiem pełnym porównań i metafor. Można powiedzieć, że jeśli autor stara się ukazać coś niewyrażalnego, to sięga po narzędzia literackie stosowane najczęściej przez poetów ${ }^{49}$. Rdzeniem języka mistycznego jest przekonanie, że poprzez zmysły można doświadczyć czegoś niewyobrażalnego. Założenie to powoduje, że język mistyczny wydaje się dla ludzi niedoświadczających podobnych stanów niedorzeczny i wewnętrznie sprzeczny ${ }^{50}$. Nagromadzenie metafor u Stasiuka przywołuje na myśl propozycje teoretyczne wiążące literaturę z mistyką, wskazujące przede wszystkim na możliwość pozapojęciowego poznania, które jest źródłem języka poetyckiego ${ }^{51}$.

Częste opisy wskazujące na nietrwałość, przemijalność istnienia zmuszają natomiast bohaterów Stasiuka do poszukiwania czegoś, co byłoby niezmienne. I wydaje się, że jedynym zjawiskiem w omawianej prozie, które nie podlegałoby zniszczeniu, może być światło. Adrian Gleń

${ }^{43}$ Cezary Woźniak, Heidegger. Da/Augenblick (Kraków: Wydawnictwo Uniwersytetu Jagiellońskiego, 2020), 20.

${ }^{44}$ Gleń, Andrzej Stasiuk. Istnienie, 61.

${ }^{45}$ Wiele z zawartych w tej recenzji własnych spostrzeżeń dotyczących religijnych odniesień w twórczości Andrzeja Stasiuka uwzględniłem m.in. w artykule: Paweł Dziel, „Inspiracje religijne w pisarstwie Andrzeja Stasiuka”, w Literatura i wiara, red. Andrzej Sulikowski (Szczecin: Wydawnictwo Print Group, 2009).

${ }^{46}$ Zob. Ursula Baatz, „Mistyka hipisowska”, w Leksykon mistyki, red. Peter Dinzelbacher, tłum. Bogusław Widła (Warszawa: Verbinum, 2002), 204-205. Mam głównie na myśli zjawisko określane nieraz jako „mistyka hipisowska", jednak termin ten zdecydowanie nie wyczerpuje zasygnalizowanej przeze mnie kontrkulturowej problematyki. Zagadnienie to rozwinąłem m.in. w artykule: Paweł Dziel, „Święte miejsca w twórczości Andrzeja Stasiuka oraz Jacka Podsiadły”, w Święte miejsca w literaturze, red. Zbigniew Chojnowski, Anna Rzymska, Beata Tarnowska (Olsztyn: Wydawnictwo Uniwersytetu Warmińsko-Mazurskiego, 2009).

${ }^{47}$ Zob. Dziel, „Inspiracje religijne w pisarstwie Andrzeja Stasiuka”.

${ }^{48}$ Gleń, Andrzej Stasiuk. Istnienie, 67.

${ }^{49}$ Mieczysław Orski, Autokreacje i mitologie (zwięzły opis spraw literatury lat 90.) (Wrocław: OKIS, 1997), 52.

${ }^{50}$ Leszek Kołakowski, Jeśli Boga nie ma... O Bogu, Diable, Grzechu i innych zmartwieniach tak zwanej filozofii religii (Kraków: Wydawnictwo Znak, 1988), 126.

${ }^{51}$ Stefan Sawicki, Wartość - sacrum - Norwid. Studia i szkice aksjologicznoliterackie (Lublin: Redakcja Wydawnictw Katolickiego Uniwersytetu Lubelskiego, 1994), 100. 
poświęca temu problemowi wiele miejsca, wnikliwie analizując różne aspekty zjawiska: „W pisarstwie Stasiuka potencja sensotwórcza zależy jednak nie tylko, co byłoby zgodne z odwieczną tradycją i hermeneutyką, od dialektyki światła (metafory sensu) i mroku (symbolu nicości), ale także - i to jest w istocie główna rzecz, której chciałbym przyjrzeć się baczniej - od rozmaitych «stopni skupienia» światła, od jego intensywności czy kąta padania, wreszcie od okoliczności, w jakich odbywa się w tej prozie rejestracja działania światła" ${ }^{" 2}$.

Ważnym argumentem na rzecz widzenia w Stasiuku pisarza religijnego jest dla opolskiego krytyka stała obecność motywu zmartwychwstania czy też wskrzeszania ${ }^{53}$. A ta problematyka ściśle łączy się z poprzednim wątkiem, czyli opisami światła. Gleń przywołuje oczekiwanie bohatera na „światło wiekuiste”, które „stężeje w płomień zdolny prześwietlić wszystko, spopielić $\mathrm{i}$ - w ten sposób przemienione - podnieść ku nieśmiertelności” ${ }^{54}$. Jednak znacznie częściej badacz ukazuje światło w prozie Stasiuka jako stymulator pamięci ${ }^{55}$. Pamięci, która „każe nam nieustannie ożywiać, jest w służbie pragnienia obecności, które silniejsze wydaje się nawet od religijnych nakazów i dogmatów regulujących pracę wyobraźni eschatologicznej"56. Stasiuk przecież pisze: „nigdy żaden pomysł na wskrzeszenie nie przyszedł mi do głowy, żaden prócz pamięci - tego bękarta czasu, nad którym nikt nigdy nie miał władzy"57. Dlatego też szczególnie ważne wydają mi się te spostrzeżenia Glenia, w których paradoksalnie motyw zmartwychwstania łączy z nieobecnością, zanikiem światła. W ten sposób analizuje ukazane w Dukli doświadczenie odrodzenia postaci Marii Amalii Mniszech z Brühlów, której kościelny grobowiec (a właściwie rzeźbę na sarkofagu) narrator regularnie odwiedza. Kluczowe jest następujące spostrzeżenie Glenia: „Rzeczywistość uwolniona od światła, od wzroku, poddaje się już tylko tym zmysłom, które działają pod dyktando wyobraźni”"58. To pamięć i wyobraźnia chronią u Stasiuka przed unicestwieniem.

Czy można traktować zatem autora Dukli jako pisarza religijnego? Moim zdanie nie. U Stasiuka odwołania do tematyki sacrum wiążą się w większej mierze z grą motywami niż z refleksją nad wiarą. Adrian Gleń zdaje się podzielać tę opinię, zaznacza bowiem, że nie przeczytamy nigdzie u Stasiuka o „pragnieniu zbawienia czy przebóstwienia” ${ }^{59}$. Badacz skłania się więc raczej do traktowania pisarza jako egzystencjalisty „tropiącego styk bycia i nicości, wypatrującego wszelkich podobieństw wizji religijnych do własnych doświadczeń i ufundowanych na nich wyobrażeńn ${ }^{60}$.

Przede wszystkim jednak z Adrianem Gleniem zgadzam się w tym, co jest tak naprawdę fundamentalne $\mathrm{w}$ jego pracy - Stasiuk pozostaje po stronie życia, po stronie istnienia. W ten

\footnotetext{
${ }^{52}$ Gleń, Andrzej Stasiuk. Istnienie, 85.

${ }^{53}$ Gleń, 173.

${ }^{54}$ Gleń, 104.

${ }^{55}$ Uważam, że w twórczości Stasiuka dominuje związany z tradycją arystotelesowską motyw światła fizykalnego (lux) - naturalnego, zmysłowo postrzegalnego zjawiska, a nie światła duchowego, boskiego (lumen). Zob. Kris Van Heuckelom, „Patrzeć w promień od ziemi odbity”. Wizualność w poezji Czesława Miłosza (Warszawa: Fundacja „Centrum Międzynarodowych Badań Polonistycznych, IBL PAN, 2004), 12-13.

${ }^{56}$ Gleń, Andrzej Stasiuk. Istnienie, 106.

${ }^{57}$ Andrzej Stasiuk, Dukla (Gładyszów: Wydawnictwo Czarne, 1999), 91.

${ }^{58} \mathrm{Gleń}$, Andrzej Stasiuk. Istnienie, 98.

${ }^{59}$ Gleń, 107.

${ }^{60}$ Gleń, 173.
} 
sposób badacz wyraźnie dystansuje się wobec myśli Martina Heideggera ${ }^{61}$, dla którego świadomość śmierci jest momentem kluczowym i pożądanym, „otwierającym jestestwu jego «najbardziej własną» możność bycia” ${ }^{2}$. Gleń pisze: „W dziele Stasiuka jednak śmierć nie stanowi - w żaden sposób i w nijakim aspekcie - zjawiska zdolnego poruszać ludzkie predyspozycje, jej doświadczenie nie otwiera absolutnej wolności i nie sprawia, aby w jakiś szczególny sposób wzmocnione zostały zdolności i możliwości człowieka doświadczającego bliskości umierania oraz przeżywającego wewnętrznie fenomen własnej śmiertelności”33.

To przede wszystkim Stasiukowe doświadczenie podróży - któremu, zdaniem badacza, najbliżej do figury włóczęgi - zdaje się najbardziej pobudzać i pamięć, i wyobraźnię. Gleń przyznaje: „Przypominanie, odpominanie - układające się w literacką rekonstrukcję teraz-trwania i ukrytej w niej przedwieczności - jest w ogóle stawką wszelkiego podróżopisania" ${ }^{64}$. I uzupełnia: „elementarne doznanie otwarcia faktu własnego istnienia odbywa się - co ważne i znamienne w kontekście myśli Heideggera - w doświadczeniu zdziwienia, dziwności czy nawet tajemnicy existentiae, którą najdotkliwiej, najintensywniej odczuwa się w podróży"65.

To, co tak fascynuje Adriana Glenia, to Stasiukowe „życio-podróżo-pisanie”. Anna Legeżyńska daje do zrozumienia, że konstruowanie cudzej biografii wymaga ocalenia jednostkowości doświadczenia spotkania z Innym. Zdaniem badaczki, takie spotkanie umożliwia właśnie zachwyt osobowością pisarza: „wyobraźnia, empatia i fascynacja tworzą hermeneutyczną ramę modalną tekstu biograficznego, którego celem - oprócz zysku pragmatycznego - jest utrwalenie jednostkowości czyjegoś losu”66. „Życiopisanie” Stasiuka jest dla Glenia zdecydowanie czymś więcej niż tylko tekstem. To, co fikcjonalne w tej prozie, zdaje się łączyć z werystycznym i tworzyć - jak to ujęła Anna Pekaniec - „swoisty modus kształtowania doświadczenia”67.

Adrian Gleń próbuje powtórzyć Stasiukową obronę istnienia. Jest to szczególnie widoczne w autobiograficzno-pastiszowych, podróżniczych częściach pracy. Być może tę potrzebę nale-

\footnotetext{
${ }^{61}$ Chciałbym jeszcze zasygnalizować, że Adrian Gleń także w innym obszarze wchodzi w dialog z argumentami Heideggera, przekraczając znacząco zakres jego koncepcji. Wyraźnie „zawierzając” Stasiukowi, niejako przyjmując jego „sposób bycia”, kontrastuje tezy filozofa na temat rzeczy (metafory: narzędzia, rękodzieła, warsztatu) z perspektywą pisarza, która wskazuje na przywiązanie do przedmiotów czy maszyn, na pewien rodzaj szacunku dla nich. Zdaniem Glenia refleksja Heideggera na temat rzeczy jest zimna, implikuje funkcjonalne uporządkowanie, zamykając rozumienie przedmiotów w obrębie pojęcia „poręczności” czy „niezawodności”. W ten sposób badacz dystansuje się od poglądów Bjørnara Olsena (postrzegającego Heideggera jako prekursora dzisiejszego „zwrotu ku rzeczom”). Zob. Gleń, 109-127.

${ }^{62}$ W Byciu i czasie Heidegger konstatuje: „Śmierć jest «najbardziej własną» możliwością jestestwa. Bycie ku tej możliwości otwiera jestestwu jego «najbardziej własną» możność bycia, w której wprost chodzi o bycie jestestwa. [...] Zrozumiana w wybieganiu bezwzględność śmierci indywidualizuje jestestwo w samo siebie. To ujednostkowienie jest sposobem, w jaki «tu oto» jest otwierane egzystencji, ono zaś uwidacznia, że tam, gdzie chodzi o najbardziej własną możność bycia, zawodzi wszelkie bycie przy tym, o co się troskamy, oraz wszelkie współbycie z innymi. Jestestwo tylko wtedy może być "właściwie sobą», gdy samo z siebie sobie to umożliwi". Martin Heidegger, Bycie i czas, tłum. Bogdan Baran (Warszawa: PWN, 2007), 331-332.

${ }^{63}$ Gleń, Andrzej Stasiuk. Istnienie, 152-153.

${ }^{64}$ Gleń, 178.

${ }^{65}$ Gleń, 167

${ }^{66}$ Legeżyńska, „«Wystarczy mocno i wytrwale zastanawiać się nad jednym życiem...» Biografistyka jako hermeneutyczne wyzwanie", 26.

${ }^{67}$ Anna Pekaniec, „Autobiografia i epistolografia w perspektywie kulturowej teorii literatury”, w Literatura polska i perspektywy nowej humanistyki, red. Romuald Cudak, Karolina Pospiszil (Katowice: Wydawnictwo Uniwersytetu Śląskiego, 2018), 263.
} 
żałoby powiązać ze zjawiskiem, które Ryszard Nycz nazwał literaturoznawstwem osobistym. Czy język Glenia nie wyraża opisanej przez Nycza potrzeby odrzucenia opozycji: afektu i intelektu, doświadczenia i rozumienia? Nycz pisze: „Rozumiemy, o czym jest tekst, o ile go doświadczamy; potrafimy go doświadczyć, o ile reaktywuje w nas i zmienia przyswojone struktury rozumienia" ${ }^{68}$. Opolski krytyk zdaje relację z procesu doświadczania Stasiukowej tajemnicy włóczęgi. Wyznaje: „Do tego służy podróżopisanie: przedłużać istnienie”69.

Muszę przyznać, że książka Adriana Glenia zrodziła we mnie silne uczucia. Z jednej strony irytowały pryncypialne tezy, brak krytycyzmu względem pisarza. Denerwowało to narzucające się, niekonsekwentne pastiszowanie. $Z$ drugiej jednak strony ujęły mnie analizy odwołujące się do doświadczania istnienia oraz bolesnej niezgody na ubywanie. Rozprawa przypomniała to, co niegdyś zachwyciło mnie u Stasiuka, a przygniecione zostało rozczarowaniem przewidywalnymi wynurzeniami, wielokrotnie eksploatowanymi metaforami, niepogłębionymi i często nieuzasadnionymi nawiązaniami do myśli filozoficznej.

Uważam, że Stasiukowy bohater jest najbardziej przekonujący wówczas, gdy porzuca metafizyczny pancerz i nie mierzy się z wielkimi nazwiskami, historycznymi rozliczeniami czy eschatologią. To nie forma eseistyczna jest żywiołem pisarza. Autorowi Opowieści galicyjskich znacznie bliżej do tak poszukiwanej przez opolskiego badacza autentyczności, gdy we fragmentach przypominających prozę poetycką oddaje moment zadziwienia przypadkowym zdarzeniem, codziennym detalem, zwykłą obecnością: osób, zwierząt, przedmiotów, a także światła, czasu, przestrzeni. I właśnie nie próbuje obudowywać tego doświadczenia filozoficznymi czy religijnymi skojarzeniami, ale relacjonuje odczuwanie materialności. Wówczas liczy się tylko istnienie, które tak akcentuje Adrian Gleń. Obecność - lub jej brak: głęboka tęsknota za istnieniem. W takich fragmentach prozy Stasiuka środki stylistyczne są świeże, rzeczywiście niepowtarzalne, momentami wręcz przeszywające. I miniatury te przepisuję na własny użytek, by czytać je jak odrębne, niezależne całości. Jak wiersze.

\footnotetext{
${ }^{68}$ Ryszard Nycz, „Tekstowe doświadczenia”, Teksty Drugie 1-2 (2010): 12. Nycz, odwołując się do ustaleń Martina Heideggera zawartych w zbiorze rozpraw W drodze do języka, przekonuje: „doświadczenie, które dochodzi do głosu (artykulacji, zapisu) w literaturze, a następnie aktywizuje się w lekturze, ma właśnie taki charakter: «całopsychocielesny» ([...] zarazem: cielesno-zmysłowy, społeczno-kulturowy, pojęciowo-językowy); współtropiczny (jako rodzaj paradoksalnej wzajemnie związanej «pasywnej aktywności» doświadczającego i doświadczanego); oraz transformacyjny (wobec i rzeczy, i podmiotu). [...] Pojęcie doświadczeniowej poetyki odnosiłoby się w tej perspektywie do opisu zarówno konkretnego wariantu prototypowej „fabuły” wydarzania się doświadczenia, jak i do specyficznego charakteru procesu doświadczeniowej referencjalności, przebiegającego trajektorię podobną wstędze Möbiusa (od zewnętrznego odniesienia przez jego „tropiczne” uwewnętrznienie po nowe, ewokowane uzewnętrznienie indeksalnej więzi z realnością)". Ryszard Nycz, Poetyka doświadczenia. Teoria - nowoczesność - literatura (Warszawa: IBL PAN, 2012), 141-143.

${ }^{69} \mathrm{Gleń}$, Andrzej Stasiuk. Istnienie, 107.
} 


\section{Bibliografia}

Baatz, Ursula. „Mistyka hipisowska”.

W Leksykon mistyki. Zredagowane przez Peter

Dinzelbacher. Przetłumaczone przez Bogusław

Widła: 204-205. Warszawa: Verbinum, 2002.

Bernacki, Marek. Tropienie Miłosza.

Hermeneutyczna „bio-grafia” Poety. Kraków:

Universitas, 2019.

Czapliński, Przemysław, Kończal, Kornelia. „Odpominanie". W Modi memorandi. Leksykon kultury pamięci. Zredagowane przez Magdalena Saryusz-Wolska, Robert Traba, współpraca Joanna Kalicka: 301-303. Warszawa: Wydawnictwo Naukowe Scholar, 2014.

Dutka, Elżbieta. „«Słowiańskie on the road» - o Europie «zwanej Środkową» w prozie Andrzeja Stasiuka". Fraza 4 (2007): 170-182.

Dziel, Paweł. „Inspiracje religijne w pisarstwie Andrzeja Stasiuka". W Literatura i wiara. Zredagowane przez Andrzej Sulikowski, 393408. Szczecin: Wydawnictwo Print Group, 2009.

- - -. „Święte miejsca w twórczości Andrzeja Stasiuka oraz Jacka Podsiadły". W Święte miejsca w literaturze. Zredagowane przez Zbigniew Chojnowski, Anna Rzymska i Beata Tarnowska, 359-367. Olsztyn: Wydawnictwo Uniwersytetu Warmińsko-Mazurskiego, 2009.

Gleń, Adrian. Andrzej Stasiuk. Istnienie. Łódź: Wydawnictwo Uniwersytetu Łódzkiego, 2019.

Heidegger, Martin. Bycie i czas. Przetłumaczone przez Bogdan Baran. Warszawa: PWN, 2007.

Hellich, Artur. „Jak rozpoznać pastisz (i odróżnić go od parodii)?". Zagadnienia Rodzajów Literackich 2 (2014): 25-38.

- - -. „Marzenie, które czyni poeta”... Autentyczność i empatia w dziele literackim Juliana Kornhausera. Kraków: Universitas, 2013.

- - -. „W tej latarni...”. Późna twórczość Mirona Białoszewskiego w perspektywie hermeneutycznej. Opole: Wydawnictwo Uniwersytetu Opolskiego, 2004.

Hoły-Łuczaj, Magdalena. Radykalny nonantropocentryzm. Martin Heidegger i ekologia głęboka. Warszawa: Wydawnictwa Uniwersytetu
Warszawskiego, Rzeszów: Wyższa Szkoła Informatyki i Zarządzania, 2018.

Januszkiewicz, Michał. W-koło hermeneutyki literackiej. Warszawa: PWN, 2007.

- - -. W poszukiwaniu sensu. Phronesis i hermeneutyka. Poznań: Wydawnictwo Naukowe UAM, 2016.

Kołakowski, Leszek. Jeśli Boga nie ma... O Bogu, Diable, Grzechu i innych zmartwieniach tak zwanej filozofii religii. Kraków: Wydawnictwo Znak, 1988.

Legeżyńska, Anna. „ «Wystarczy mocno i wytrwale zastanawiać się nad jednym życiem...» Biografistyka jako hermeneutyczne wyzwanie". Teksty Drugie 1 (2019): 13-27.

Lorenc, Włodzimierz. Filozofia hermeneutyczna. Inspiracje, klasycy, radykalizacje. Warszawa: Wydawnictwa Uniwersytetu Warszawskiego, 2019.

- - -. Hermeneutyczne koncepcje człowieka 2. Dilthey, Misch, Bollnow. Warszawa: Wydawnictwo Naukowe „Scholar”, 2008.

Majewski, Piotr. „Przeglądanie się w Cyganie: obraz Innego w prozie Andrzeja Stasiuka". Sprawy Narodowościowe 32 (2008): 151-163.

Michalski, Krzysztof. Heidegger i filozofia wspótczesna. Warszawa: Państwowy Instytut Wydawniczy, 1978.

Mitosek, Zofia. „Hermeneuta i autobiografia”. Teksty Drugie 3 (2002): 137-151.

Nycz, Ryszard. Język modernizmu. Prolegomena historycznoliterackie. Toruń: Wydawnictwo Naukowe Uniwersytetu Mikołaja Kopernika, 2013.

- - -. Poetyka doświadczenia. Teoria nowoczesność - literatura. Warszawa: IBL PAN, 2012.

- - -. „Tekstowe doświadczenia”. Teksty Drugie 1-2 (2010): 6-12.

- - -. Tekstowy świat. Poststrukturalizm a wiedza o literaturze. Warszawa: IBL, 1993.

Orski, Mieczysław. Autokreacje i mitologie (zwięzty opis spraw literatury lat 90.). Wrocław: OKIS, 1997. 
Pekaniec, Anna. „Autobiografia i epistolografia w perspektywie kulturowej teorii literatury". W Literatura polska i perspektywy nowej humanistyki. Zredagowane przez Romuald Cudak i Karolina Pospiszil: 254-265.

Katowice: Wydawnictwo Uniwersytetu Śląskiego, 2018.

Poulet, Georges. „Krytyka identyfikująca się”. Przetłumaczone przez Judyta ZbierskaMościcka. W Szkoła Genewska w krytyce. Antologia, wybór Henryk Chudaki i in., przedmowa Maciej Żurowski: 158-169. Warszawa: PWN, 1998.

„Projekt: Egzystencja i Literatura”, https:// wydawnictwo.uni.lodz.pl/serie/seria/projektegzystencja-i-literatura/ (dostęp: 10.01.2021).

Rorty, Richard. „Kariera pragmatysty”. W Umberto Eco oraz Richard Rorty i in., Interpretacja i nadinterpretacja. Zredagowane przez Stefan Collini. Przetłumaczone przez Tomasz Biedroń: 88-107. Kraków: Wydawnictwo Znak, 1996.

Sawicki, Stefan. Wartość - sacrum - Norwid. Studia i szkice aksjologicznoliterackie. Lublin: Redakcja Wydawnictw Katolickiego Uniwersytetu Lubelskiego, 1994.

Skórczewski, Dariusz. „Kompleks(y) środkowego Europejczyka”, Opcje 2 (2008): 10-11.

Sobolczyk, Piotr. „Hermeneutyka tak, ale jaka?”. Teksty Drugie 1/2 (2006): 151-157.

Stasiuk, Andrzej. Dukla. Gładyszów: Wydawnictwo Czarne, 1999.

Szmidt, Olga. Autentyczność: stan krytyczny. Problem autentyczności w kulturze XXI wieku. Kraków: Universitas, 2019.
Van Heuckelom, Kris. „Patrzeć w promień od ziemi odbity”. Wizualność w poezji Czesława Miłosza. Warszawa: Fundacja „Centrum Międzynarodowych Badań Polonistycznych, IBL PAN, 2004.

Winiecka, Elżbieta. „O sylleptyczności tekstu literackiego". Pamiętnik Literacki 4 (2004): 137-157.

Woźniak, Cezary. Heidegger. Da/Augenblick. Kraków: Wydawnictwo Uniwersytetu Jagiellońskiego, 2020.

„Życie i literatura: Hartwig, Miłosz, Stasiuk", https://www.youtube.com/ watch? $\mathrm{v}=\mathrm{NwKQmPMU2BQ} \& \mathrm{t}=1501 \mathrm{~s}$ (dostęp: 10.01.2021). 


\title{
SŁOWA KLUCZOWE:
}

\author{
F A S C Y N A C J A
}

hermeneutyka

dos wiadczenie

pastis z

\begin{abstract}
AbStrakT:
W artykule omówiono książkę Adriana Glenia Andrzej Stasiuk. Istnienie, która odwołuje się do tradycji hermeneutycznej w badaniach literackich. Perspektywę, z której Gleń analizuje prozę Stasiuka, w dużym stopniu wyznaczają problemy podjęte przez Martina Heideggera, a także postulaty „krytyki identyfikującej się” przedstawiciela szkoły genewskiej Georges’a Pouleta. Praca ukazuje szerszy kontekst zagadnień dotyczących autobiografizmu, polemizując z zaproponowaną przez Glenia interpretacją „bez biograficznych natręctw”. Omówione zostały również trudności metodologiczne związane z uprawianiem krytyki literackiej pod wpływem fascynacji analizowaną twórczością. Autor szczególnie wyeksponował te praktyki literaturoznawcze, które eksplorują kategorię doświadczenia.
\end{abstract}




\section{autobiografizm}

Andrzej Stasiuk

\section{Martin Heidegger}

\section{NOTA O AUTORzE:}

Paweł Dziel - doktorant na Wydziale Humanistycznym Uniwersytetu Szczecińskiego. Przygotowuje pracę doktorską na temat eseistyki Barbary Skargi. Autor artykułów naukowych oraz szkiców krytycznych z zakresu współczesnej literatury polskiej. Publikował m.in. w „Pograniczach” i „Autobiografii”. Główne obszary zainteresowań badawczych obejmują eseistykę, autobiografizm oraz relacje między filozofią a literaturą. 